\title{
Elevated Growth Hormone Secretory Rate in Premature Infants: Deconvolution Analysis of Pulsatile Growth Hormone Secretion in the Neonate
}

\author{
NANCY M. WRIGHT, FRANCES J. NORTHINGTON, JOHN D. MILLER, \\ JOHANNES D. VELDHUIS, AND ALAN D. ROGOL \\ Departments of Pediatrics [N.M.W., F.J.N., A.D.R.] and Pharmacology [A.D.R.], National Science Foundation \\ Science and Technology Center for Biological Timing [J.D.V., A.D.R.], Department of Internal \\ Medicine [J.D.V.], University of Virginia Health Sciences Center, Charlottesville, Virginia 22908 and \\ Department of Pediatrics, University of California, Irvine [J.D.M], Irvine, California 92717
}

\begin{abstract}
Premature infants have higher circulating concentrations of growth hormone $(\mathrm{GH})$ than term infants. Previous investigations of these differences have used sampling frequencies of every $30 \mathrm{~min}$ with subsequent application of pulse detection algorithms, such as the CLUSTER program, to assess serum GH pulse parameters. To determine differences in GH secretory rates or GH $t_{1 / 2}$ values between premature and term infants, we have sampled 11 neonates at 15-min intervals. We performed deconvolution analysis of the resultant plasma GH values to estimate GH secretory and clearance parameters. Five premature infants (gestational age range 24-34 wk) and six term infants (gestational age range 38-42 wk) were sampled every $15 \mathrm{~min}$ for $6 \mathrm{~h}$. All subjects had indwelling arterial catheters. GH was measured (in duplicate) by RIA using $10 \mu \mathrm{L}$ of plasma. Premature infants had higher secretory burst amplitudes $(2.2 \pm 0.13 \mu \mathrm{g} / \mathrm{L} / \mathrm{min}$ versus 1.4 $\pm 0.27 \mu \mathrm{g} / \mathrm{L} / \mathrm{min}, p=0.02$ ), higher production rates (product of the total number of bursts and the mean mass of GH secreted per burst, $811 \pm 173 \mu \mathrm{g} / \mathrm{L} / 6 \mathrm{~h}$ versus $283 \pm$ $77 \mu \mathrm{g} / \mathrm{L} / 6 \mathrm{~h}, p=0.03$ ), and a higher mass of $\mathrm{GH}$ per secretory burst $(106 \pm 25 \mu \mathrm{g} / \mathrm{L}$ versus $38 \pm 11 \mu \mathrm{g} / \mathrm{L}, p=$ $0.049)$ than term infants. The integrated plasma GH concentration exhibited a strong trend toward a higher value in the premature infants $(18100 \pm 800 \mu \mathrm{g} / \mathrm{L}$ versus 10200 $\pm 2700 \mu \mathrm{g} / \mathrm{L}, p=0.067)$. There were no differences between GH secretory burst frequency $(7.8 \pm 0.2$ pulses $/ 6$ $h$ versus $7.7 \pm 0.6$ pulses $/ 6 \mathrm{~h}), G \mathrm{GH} \mathrm{t}_{1 / 2}(20 \pm 4 \mathrm{~min}$ versus $24 \pm 6 \mathrm{~min}$ ), half-duration of burst (the time elapsed at half-maximal amplitude, $45 \pm 11$ min versus $25 \pm 4$ min), or mean interval between peaks $(48 \pm 2$ min versus $48 \pm 3$ min) comparing the premature and term groups, respectively. In summary, we have demonstrated an elevation in GH secretory burst amplitude, GH production rate, and the mass of GH secreted per burst in premature compared with term infants. Because the estimated $G H t_{1 / 2}$ is similar between these two groups, amplified secretion rather than decreased clearance accounts for the differences in circulating GH concentrations. We suggest that the augmented GH secretory activity in premature infants reflects an
\end{abstract}

Received February 10, 1992; accepted May 12, 1992.

Correspondence and reprint requests: Nancy M. Wright, M.D., University of Virginia Health Sciences Center, Division of Endocrinology, Department of Pediatrics, Lane Road, MR-4 Room 3037, Charlottesville, VA 22908.

Supported in part by The Center for Research in Reproduction Training Grant (to N.M.W.), by the General Clinical Research Center (RR 00847), and by NIH RCDA no. 01 K04 HD 00634 (J.D.V.) from NICHD. increase in hypothalamic GH-releasing hormone activity and/or reduced somatostatin tone. (Pediatr Res 32: 286$290,1992)$

\section{Abbreviations}

GH, growth hormone

GA, gestational age

GHRH, growth hormone-releasing hormone

SRIF, somatostatin

GH is first detectable in the human fetal pituitary by 9 wk of gestation (1). The physiologic importance of $\mathrm{GH}$ for growth prenatally is unclear. Several investigators have documented higher $\mathrm{GH}$ concentrations in fetuses and premature infants compared with term infants by measuring $\mathrm{GH}$ in either single serum samples from aborted fetuses (1) or single cord blood samples (2). A similar phenomenon has been well documented in fetal sheep (3). With the discovery that GH secretion after birth is intermittent (4), investigators have more recently examined these pulsatile parameters in fetal and early life. Bassett and Gluckman (5) have measured ovine fetal circulating GH concentrations every $20 \mathrm{~min}$ for $3 \mathrm{~h}$ and demonstrated significantly higher hormone levels than in full-term neonatal sheep. Miller et al. (6) measured human plasma GH concentrations every 30 min over a 12 -h period in 15 premature and eight term infants and found a strong trend toward higher $\mathrm{GH}$ concentrations in the premature group.

To date it has not been possible to determine whether this observed increase in $\mathrm{GH}$ concentration in premature infants relative to term infants is secondary to increased secretion of $\mathrm{GH}$ or rather is a result of decreased GH clearance. Moreover, the neuroendocrine mechanism for increased secretion might entail amplified GH secretory burst amplitude or frequency, or both. We have measured and compared $\mathrm{GH}$ concentrations at frequent intervals in premature and term human infants and have applied deconvolutional modeling to differentiate $\mathrm{GH}$ secretory from clearance function. We also evaluated changes in the frequency, amplitude, mass, and/or duration of underlying GH secretory bursts.

\section{MATERIALS AND METHODS}

Subjects. Eleven infants from the neonatal intensive care units at The University of Virginia (10 subjects) and the University of 
California-Irvine (one subject) were recruited for the study. Protocols were approved by the Human Investigation Committee at each institution. Eligibility criteria included the following: age between 24 and $96 \mathrm{~h}$, preexisting indwelling arterial cannulas, and minimal or no ventilatory support. Informed parental consent was obtained for all subjects. Infants with congenital anomalies and infants receiving vasopressor drugs were excluded.

Infants were sampled for $\mathrm{GH}(0.1 \mathrm{~mL}$ of blood per sample) every $15 \mathrm{~min}$ for a 6 -h period and one for IGF-I $(0.1 \mathrm{~mL}$ blood $)$. Glucose and hematocrit determinations were made twice. The total amount of blood taken during the 6-h study was $2.8 \mathrm{~mL}$. No infant had been fed before the study and all were receiving i.v. glucose and electrolyte-containing fluids. Parenteral nutrition was not given during the study.

Assays. Blood samples were centrifuged at $12500 \mathrm{rpm}$ for 3 min, and the plasma was removed and stored in labeled plastic vials on ice. Samples for IGF-I were collected in $0.4-\mathrm{mL}$ vials containing EDTA. Upon completion of the 6-h study period, all samples were stored at $-80^{\circ} \mathrm{C}$ until analysis.

$\mathrm{GH}$ was measured in heparinized plasma by a modification of a double-antibody RIA (Diagnostic Products, Los Angeles, CA) using $10 \mu \mathrm{L}$ of plasma. This sample was diluted with $40 \mu \mathrm{L}$ of kit standard to attain the requisite $50 \mu \mathrm{L}$ of assay volume, and samples were run in duplicate. The range of detectability for these diluted samples in this assay was $1.0-30 \mu \mathrm{g} / \mathrm{L}$. The values of these diluted samples were then determined by multiplying by 5 . The intraassay coefficient of variation and interassay coefficient of variation were 6.2 and $7.3 \%$, respectively.

IGF-I was measured in EDTA plasma after separation of IGFI from its binding proteins using octadecasilyl-silica cartridges (C18 Sep Pak; Waters, Milford, MA). The serum samples were not acid-chromotographed, and total IGF binding protein was not determined. IGF-I kits were purchased from Nichols Institute (San Juan Capistrano, CA). The intraassay coefficient of variation and interassay coefficient of variation were $1.1 \pm 0.7 \%( \pm$ SD) and $11 \%$, respectively.

Deconvolutional modeling. Previously, neonatal pulsatile $\mathrm{GH}$ characteristics have been assessed using pulse detection algorithms (6) such as CLUSTER $(7,8)$. This program analyzes observed GH concentrations over time (Fig. 1, top panel). The circulating $\mathrm{GH}$ concentration at any given point in time can be described by a convolution integral, which reflects assay accuracy and simultaneous GH secretion and clearance (Fig. 2). To determine true $\mathrm{GH}$ secretory parameters and to estimate $\mathrm{GH}$ clearance function from this convolution integral (Fig. 2, right panel), we have used deconvolutional modeling. This computerized analysis has been described previously (9). It separates secretory (Fig. 2, left panel) and clearance function (Fig. 2, middle panel) in each subject. Figure 1 (middle panel) shows a continuous curve, which represents expected $\mathrm{GH}$ concentrations if discrete $\mathrm{GH}$ secretory bursts had occurred as predicted by deconvolution analysis. Figure 1 (bottom panel) shows the presumptively gaussian secretory bursts that were predicted by this analysis. Parameters with statistical confidence intervals for each burst including amplitude (maximal rate of secretion within a burst), half-duration (the time elapsed at half-maximal amplitude), temporal positions, and $\mathrm{GH} \mathrm{t}_{1 / 2}$ can then be determined. No interburst secretory activity was required to model the present data. The mass of GH secreted per burst (the area under the curve of the secretory burst), the GH production rate (product of the total number of bursts and the mean mass of GH released per burst), and the mean time interval between bursts were also determined.

Statistics. Unpaired two-tailed $t$ tests were performed on the following $\mathrm{GH}$ deconvolution parameters: secretory burst amplitude, production rate, mass of $\mathrm{GH}$ per secretory burst, integrated plasma $\mathrm{GH}$ concentrations, $\mathrm{GH} \mathrm{t}_{1 / 2}$, and half duration of secretory burst. Because of departures from normality as defined by the Wilkes-Shapiro statistic, the GH secretory burst frequency and mean interval between bursts were analyzed using the Wilcoxon
$60-$

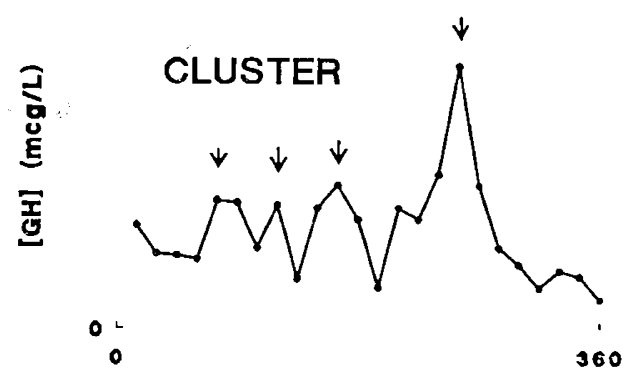

$60-$
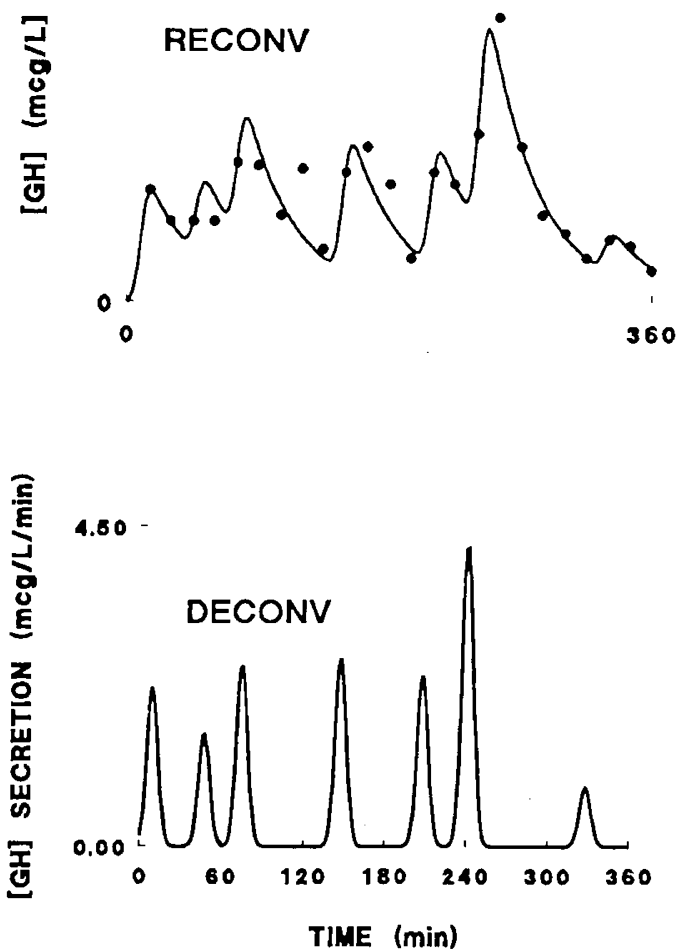

Fig. 1. Schema of GH secretion. Top panel shows results of CLUSTER analysis of plasma GH concentrations over time (arrows denote peaks). Middle panel depicts $\mathrm{GH}$ concentrations as above, in addition to reconvolved fit of these data as predicted by deconvolution analysis. Bottom panel reveals computer-identified GH secretory bursts, which account for observed GH concentrations.

rank sum test. Data are reported as the mean \pm SEM. Significance was accepted at $p<0.05$.

\section{RESULTS}

Growth, demographic, diagnostic, and clinical summaries for the five preterm and six term infants studied are shown in Table 1. All infants were clinically stable; most preterm infants with mild, resolving respiratory distress syndrome had received intratracheally at least one dose of calf lung surfactant extract. The term infants had a variety of pulmonary-cardiovascular conditions requiring treatment, but none was receiving more than $62 \% \mathrm{O}_{2}$ by hood at the time of the study. All of the preterm infants were of appropriate height and weight for GA as determined by Ballard examination. One of the term infant's weight was at the 5th percentile for his GA and another infant's weight 
A

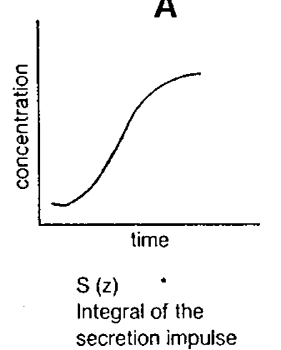

B

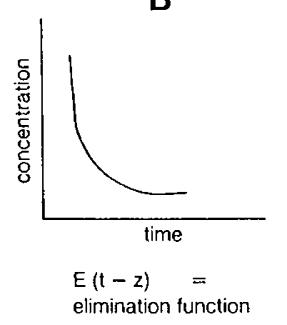

C

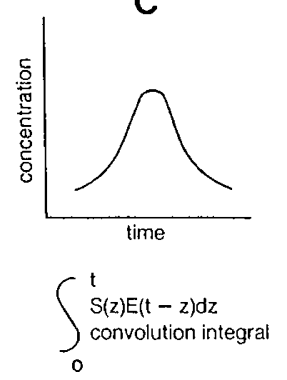

Fig. 2. Schematic illustration of deconvolutional modeling. Hormonal concentrations at any given point in time $(C)$ reflect the effects of prior and simultaneous secretory impulses $(A)$ and endogenous subject-specific metabolic clearance $(B)$. Reprinted from Pediatr Res 28:626, 1990 with permission of the International Pediatric Research Foundation, Inc.

was greater than the 95 th percentile for GA. Neither infant required more than physiologic amounts of glucose to maintain a normal circulating glucose concentration. The average age at study for the preterm infants was $67.6 \pm 4.3 \mathrm{~h}$ and for the term infants, $53.8 \pm 9.4 \mathrm{~h}$. All but one were receiving ampicillin and gentamicin at the time of the study, but none had positive blood cultures.

Family history was negative for growth hormone deficiency or short stature.

Figure 3 displays secretory rate versus time of two representative subjects (subject 1, a 25-wk GA premature infant and subject 6, a 38-wk GA term infant).

Premature infants had higher secretory burst amplitudes ( 2.2 $\pm 0.13 \mu \mathrm{g} / \mathrm{L} / \mathrm{min}$ versus $1.4 \pm 0.27 \mu \mathrm{g} / \mathrm{L} / \mathrm{min}, p=0.02$ ), higher production rates $(811 \pm 173 \mu \mathrm{g} / \mathrm{L} / 6 \mathrm{~h}$ versus $283 \pm 77 \mu \mathrm{g} / \mathrm{L} / 6$ h, $p=0.03)$, and a greater mass of GH per secretory released burst $(106 \pm 25 \mu \mathrm{g} / \mathrm{L}$ versus $38 \pm 11 \mu \mathrm{g} / \mathrm{L}, p=0.049)$. The integrated plasma GH concentration exhibited a strong trend toward a greater value in the premature infants $(18100 \pm 800$ $\mu \mathrm{g} / \mathrm{L}$ versus $10200 \pm 2700 \mu \mathrm{g} / \mathrm{L}, p=0.067)$. There were no differences between GH secretory burst frequency $(7.8 \pm 0.2$ pulses $/ 6 \mathrm{~h}$ versus $7.7 \pm 0.6$ pulses $/ 6 \mathrm{~h}), \mathrm{GH} \mathrm{t}_{1 / 2}(20 \pm 4 \mathrm{~min}$ versus $24 \pm 6 \mathrm{~min}$ ), half-duration of bursts ( $45 \pm 11 \mathrm{~min}$ versus $25 \pm 4 \mathrm{~min}$ ), or mean interval between secretory burst $(48 \pm 2$ min versus $48 \pm 3 \mathrm{~min}$ ) in the premature and term groups, respectively (Table 2).

The IGF-I concentrations in the premature and term groups $[11.5 \pm 1.2 \mathrm{ng} / \mathrm{mL}(1.50 \mathrm{nmol} / \mathrm{L})$ and $27.1 \pm 7.5 \mathrm{ng} / \mathrm{mL}(3.5$ $\mathrm{nmol} / \mathrm{L})$, respectively] suggest a trend $(p=0.09)$ toward lower IGF-I concentrations in the premature group.

\section{DISCUSSION}

Our comparison of pulsatile $\mathrm{GH}$ secretion parameters between premature and term neonates shows higher secretory burst amplitudes, production rates, and mass of GH released per secretory burst in the premature infants. These changes were specific, inasmuch as the calculated $\mathrm{GH} \mathrm{t}_{1 / 2}$ values did not differ between the two groups. The $\mathrm{GH} \mathrm{t} \mathrm{t}_{1 / 2}$ values of 20 and $24 \mathrm{~min}$ for premature and term infants, respectively, are similar to those reported for normal adult men $(18.9 \mathrm{~min})(10)$ and for children $(19 \mathrm{~min})$ (11). These values differ from the mean $\mathrm{GH} \mathrm{t} t_{1 / 2}$ of $12 \mathrm{~min}$, estimated in four term infants by Cornblath $e t$ al. (2), who found a range of 11-14 min. This discrepancy may reflect a difference in the $t_{1 / 2}$ of exogenous, cadaveric GH and our estimate of endogenous GH. Additionally, Faria et al. (10) recommended measurements of four or five $t_{1 / 2}$ values to best determine $\mathrm{GH} t_{1 / 2}$. To our knowledge, estimates of $\mathrm{GH} \mathrm{t}_{1 / 2}$ in premature infants have not previously been determined. The present data indicate that the high circulating GH concentrations observed in premature infants are a result of greater pituitary secretion rather than decreased metabolic clearance.

Pituitary GH secretion is regulated by hypothalamic secretion of GHRH and SRIF (12). Gluckman and Parsons (13) have demonstrated that GH secretion in fetal lambs requires an intact hypothalamus. An increase in GHRH or a decrease in SRIF secretion could explain the elevated GH levels in the premature infant. Inasmuch as all plasma $\mathrm{GH}$ concentrations were detectable, decreased SRIF inhibitory tone with or without augmented amounts of GHRH released per pulse, and/or enhanced somatotroph cell responsiveness to GHRH, could account for our findings.

Kaplan et al. (1) have proposed that elevated fetal GH concentrations result from an immaturity of hypothalamic control of the pituitary somatotroph. Alternatively, decreased inhibition of hypothalamic function could explain this increased stimulation of the pituitary by the hypothalamus in the premature infant. A known inhibitor of hypothalamic and pituitary function regulating GH secretion by somatotrophs is IGF-I $(14,15)$. We found a tendency toward lower total IGF-I levels in the premature group. These data support previous findings of studies with greater numbers of subjects that total IGF-I concentrations are lower in premature infants $(6,16,17)$ or in fetal porcine models (18). Thus the lower levels of total IGF-I in premature infants could result in less inhibitory feedback on the hypothalamopituitary unit, resulting in augmented GH secretion from the pituitary.

Inasmuch as the majority of IGF-I in humans is complexed to IGF binding proteins, particularly IGF binding protein-3 (19), these proteins may play an important role in this pathway. IGF binding protein- 3 concentrations rise from the neonatal period through puberty (20). Miller et al. (6) have shown that premature

Table 1. Individual subject clinical data*

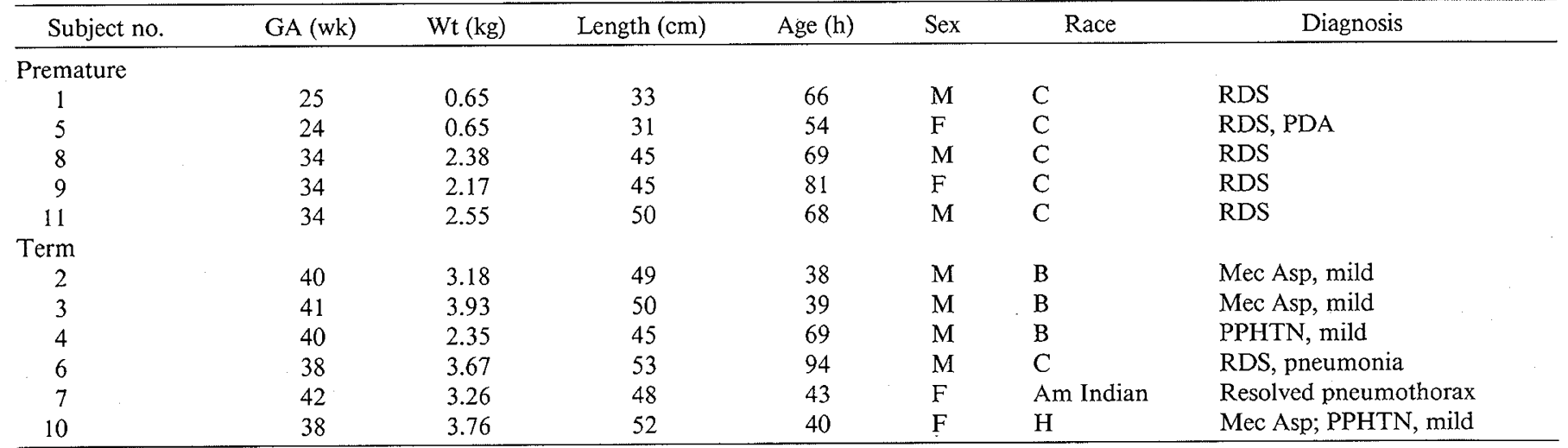

* Abbreviations: RDS, respiratory distress syndrome; PPHTN, persistent pulmonary hypertension; PDA, patent ductus arteriosus; Mec Asp, meconium aspiration; B, black; C, Causasian; $\mathrm{H}$, Hispanic. 
PREMATURE INFANT
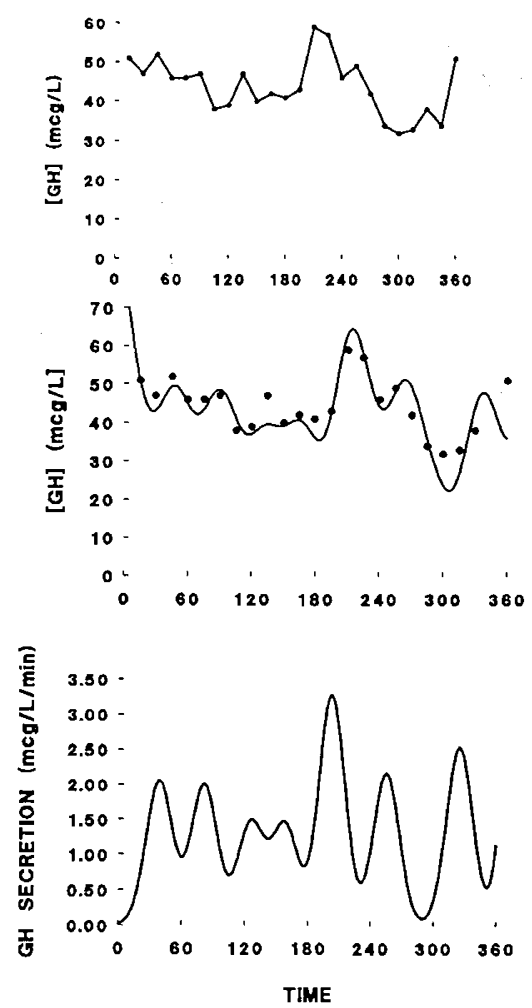

TERM INFANT
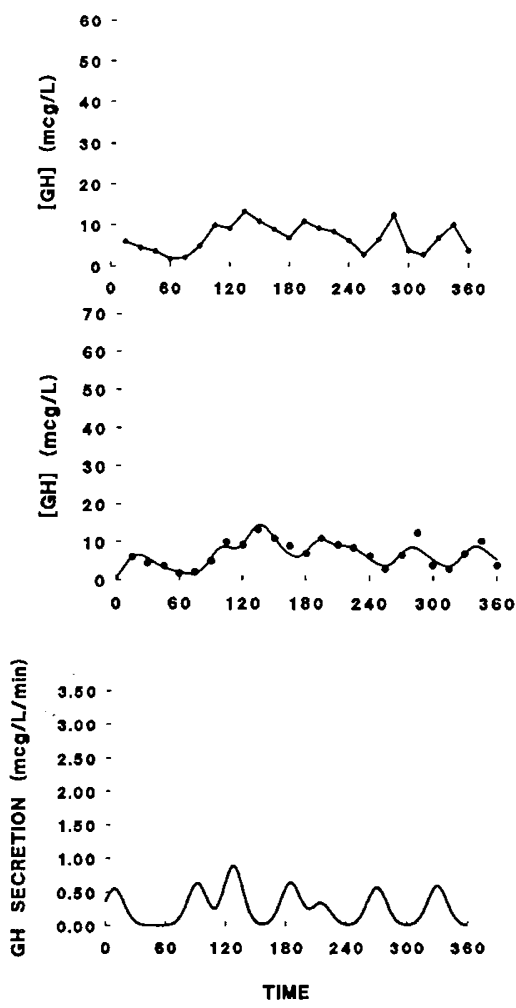

Fig. 3. GH secretory profiles of two representative subjects (a 25-wk gestation premature male infant on the left and a 38-wk term male infant on the right). Top panel depicts observed plasma GH concentrations $(\mu \mathrm{g} / \mathrm{L})$ over time (min), plotted using CLUSTER. Middle panel shows discrete GH concentrations as above, in addition to reconvolved fit of these data predicted by deconvolution analysis shown by the continuous line. Bottom panel represents deconvolved secretory bursts over time, which account for observed GH concentrations (secretory rate, $\mu \mathrm{g} / \mathrm{L} / \mathrm{min} v s$ time).

Table 2. GH secretory burst parameters*

\begin{tabular}{lcc}
\hline & Premature & Term \\
\hline Amplitude $(\mu \mathrm{g} / \mathrm{L} / \mathrm{min})$ & $2.2 \pm 0.1 \dagger$ & $1.4 \pm 0.3$ \\
Production rate $(\mu \mathrm{g} / \mathrm{L} / 6 \mathrm{~h})$ & $811 \pm 173 \dagger$ & $283 \pm 77$ \\
GH mass/burst $(\mu \mathrm{g} / \mathrm{L})$ & $106 \pm 25 \dagger$ & $38 \pm 11$ \\
Integrated serum $[\mathrm{GH}](\mu \mathrm{g} / \mathrm{L}) \ddagger$ & $18100 \pm 800$ & $10200 \pm 2700$ \\
Burst frequency (pulses/6 $/ \mathrm{h})$ & $7.8 \pm 0.2(8)$ & $7.7 \pm 0.6(7)$ \\
$t_{1 / 2}($ min) & $20 \pm 4$ & $24 \pm 6$ \\
Half-duration of burst (min) & $45 \pm 11$ & $25 \pm 4$ \\
Mean peak interval (min) & $48 \pm 2(45)$ & $48 \pm 3(53)$ \\
\hline
\end{tabular}

* Comparison of GH secretory burst parameters (mean \pm SEM) between the premature infant and term infant groups. Median values are shown in parentheses for parameters analyzed nonparametrically.

$\dagger$ Statistically significant between-group differences $(p<0.05)$.

$\ddagger[\mathrm{GH}]$, GH concentration.

infants have significantly lower IGF binding protein-3 concentrations than do term infants. Additionally, IGF binding protein2 , which is present in greatest concentration prenatally, and increases with development in the fetal pig (21), may also affect this pathway.

Tanner (22) has suggested an inhibitory influence of IGF-I on GH secretion in general. Decreased IGF-I feedback on the neonatal hypothalamopituitary unit ultimately resulting in elevated circulating $\mathrm{GH}$ concentrations in the premature infant may be accounted for by an additional explanation. Specifically, GH traditionally results in an elevation of IGF-I concentrations, yet the opposite is found in premature infants. Exceptions to this rule are also found in several pathophysiologic conditions including Laron-type dwarfism, which is associated with abnormality of the $\mathrm{GH}$ receptor $(23)$, and starvation states $(24,25)$. Relative quantitation of the $\mathrm{GH}$ receptor can be indirectly obtained by measurement of $\mathrm{GH}$ binding protein, a putative $\mathrm{GH}$ receptor degradation product. $\mathrm{GH}$ binding protein concentrations are low in human premature infants (26) compared with their term counterparts. These data suggest that the altered GH axis in the premature infant may result primarily from an immaturity of the $\mathrm{GH}$ receptor, specifically a lower receptor number.

In summary, we have investigated the pulsatile nature of $\mathrm{GH}$ secretion in premature and term infants by frequent blood sampling. Application of deconvolutional modeling to these data has shown that the elevated circulating $\mathrm{GH}$ concentrations found in premature infants are a result of increased pulsatile $\mathrm{GH}$ secretion, with a greater mass of $\mathrm{GH}$ secreted per burst, not decreased $\mathrm{GH}$ clearance. In view of the present body of neonatal GH data, we suggest that decreased tissue actions of GH and reduced IGF-I negative feedback may explain the physiologic state of accentuated $\mathrm{GH}$ secretion in the premature newborn.

Acknowledgments. The authors thank Susan L. Fitzgerald for the professional manuscript preparation. We are indebted to the staff of the Neonatal Intensive Care Unit at The University of Virginia, in particular the laboratory technicians. We also thank Ginger Bauler and Katherine Kern of the General Clinical Research Center Core lab at The University of Virginia for $\mathrm{GH}$ analysis and Regina Jansons at The University of California, Irvine for IGF-I and GH analysis.

\section{REFERENCES}

1. Kaplan SL, Grumbach MM, Shepherd TH 1972 The ontogenesis of human fetal hormones. I. Growth hormone and insulin. J Clin Invest 51:3080-3093

2. Cornblath M, Parker ML, Reisner SH, Forbes AE, Daughaday WH 1965 Secretion and metabolism of growth hormone in premature and full-term infants. J Clin Endocrinol 25:209-218

3. Gluckman PD, Mueller PL, Kaplan SL, Rudolph AM, Girumbach MM 1979 Hormone ontogeny in the ovine fetus. I. Circulating growth hormone in mid and late gestation. Endocrinology 104:162-168 
4. Davis SL, Ohlson DL, Klindt J, Anfinson MS 1977 Episodic growth hormone secretory patterns in sheep: relationship to gonadal steroids hormones. Am J Physiol 233:E519-E523

5. Bassett NS, Gluckman PD 1986 Pulsatile growth hormone secretion in the ovine fetus and neonatal lamb. J Endocrinol 109:307-312

6. Miller JD, Chien EY, Record MR, Szeto V, Havenhill L, Mosier HD 1991 Insulin-like growth factors (IGF-I and IGF-II), IGF binding protein-3 and spontaneous growth hormone $(\mathrm{GH})$ release in premature and term infants Program of the 73rd meeting of the Endocrine Society, Washington, DC abstr 459

7. Urban RJ, Evans WS, Rogol AD, Kaiser DL, Johnson ML, Veldhuis JD 1988 Contemporary aspects of discrete peak-detection algorithms. I. The paradigm of the luteinizing hormone pulse signal in men. Endocrinol Rev 9:3-37

8. Veldhuis JD, Johnson ML 1986 Cluster analysis: a simple, versatile, and robust algorithm for endocrine pulse detection. Am J Physiol 250:E486-E493

9. Veldhuis JD, Carlson ML, Johnson ML 1987 The pituitary gland secretes in bursts: appraising the nature of glandular secretory impulses by simultaneous multiple-parameter deconvolution of plasma hormone concentrations. Proc Natl Acad Sci USA 84:7686-7690

10. Faria AC, Veldhuis JD, Thorner MO, Vance ML 1989 Half-time of endogenous growth hormone $(\mathrm{GH})$ disappearance in normal man after stimulation of $\mathrm{GH}$ secretion by $\mathrm{GH}$-releasing hormone and suppression with somatostatin. $\mathrm{J}$ Clin Endocrinol Metab 68:535-541

11. Mauras N, Rogol AD, Veldhuis JD 1990 Increased hGH production rate after low-dose estrogen therapy in prepubertal girls with Turner's syndrome. Pediatr Res 28:626-630

12. Tannenbaum GS, Ling $N 1984$ The interrelationship of growth hormone (GH)-releasing factor and somatostatin in generation of the ultradian rhythm of GH secretion. Endocrinology 115:1952-1957

13. Gluckman PD, Parsons Y 1985 Growth hormone secretion in the fetal sheep following stereotaxic electrolytic lesioning of the fetal hypothalamus. J Dev Physiol 7:25-36

14. Berelowitz M, Szabo M, Frohman LA, Firestone S, Chu L 1981 Somatomedin$\mathrm{C}$ mediates growth hormone negative feedback by effects on both the hypothalamus and the pituitary. Science 212:1279-1281

15. Yamashita S, Melmed S 1986 Insulin-like growth factor I action on rat anterior pituitary cells: suppression of growth hormone secretion and messenger ribonucleic acid levels. Endocrinology 118:176-182

16. Ashton ID, Zapf F, Einschenk I, Mackenzie IZ 1985 Insulin-like growth factors (IGF)-1 and (IGF)-2 in human foetal plasma and relationship to gestational age and foetal size during mid-pregnancy. Acta Endocrinol (Copenh) 110:558-563

17. Bennett A, Wilson DM, Liu F, Nagashima R, Rosenfeld RG, Hintz RL 1983 Levels of insulin-like growth factors I and II in human cord blood. J Clin Endocrinol Metab 57:609-612

18. Lee YC, Bazer FW, Etherton TD, Simmen FA 1991 Ontogeny of insulin-like growth factors (IGF-1 and IGF-II) and IGF-binding proteins in porcine serum during fetal and postnatal development. Endocrinology 128:23362343

19. Hintz RL, Liu F, Rosenfeld RG, Kemp SR 1981 Plasma somatomedin-binding proteins in hypopituitarism changes during growth hormone therapy. $\mathrm{J}$ Clin Endocrinol Metab 53:100-104

20. Clemmons DR 1990 Insulin-like growth factor binding proteins. Trends in Endocrinology and Metabolism 1:412-417

21. McCusker RH, Campion DR, Jones WK, Clemmons DR 1989 The insulinlike growth factor binding proteins of porcine serum: endocrine and nutritional regulation. Endocrinology 125:501-509

22. Tanner JM 1972 Human growth hormone. Nature 237:433-439

23. Laron Z, Karp M, Pertzelan A, Kauli R, Keret R, Doron M 1971 The syndrome of familial dwarfism and high plasma immunoreactive human growth hormone (IR-HGH). In: Pecile A, Mueller E (eds) Growth and Growth Hormone. Milan Excerpta Medica, Amsterdam, pp 458-482

24. Hartman ML, Veldhuis JD, Johnson ML, Lee MM, Alberti KGMM, Samojlik E, Thorner MO 1992 Augmented growth hormone (GH) secretory burst frequency and amplitude mediate enhanced $\mathrm{GH}$ secretion during a two-day fast in normal men. J Clin Endocrinol Metab 74:757-765

25. Soliman AT, Hassan AEHI, Aref MK, Hintz RL, Rosenfeld RG, Rogol AD 1986 Serum insulin-like growth factors I and II concentrations and growth hormone and insulin responses to arginine infusion in children with proteinenergy malnutrition before and after nutritional rehabilitation. Pediatr Res 20:1122-1130

26. Daughaday WH, Trivedi B, Andrews BA 1987 The ontogeny of serum GH binding proteins in man: a possible indicator of hepatic $\mathrm{GH}$ receptor development. J Clin Endocrinol Metab 65:1072-1074 